Abstracta Iranica

Revue bibliographique pour le domaine irano-aryen

Volume 37-38-39 | 2018

Comptes rendus des publications de 2014-2016

\title{
Rika Gyselen. «The Parthian Language in Early Sasanian Times »
}

\section{Julien Cuny}

\section{(2) OpenEdition \\ 12 Journals}

\section{Édition électronique}

URL : http://journals.openedition.org/abstractairanica/46351

DOI : 10.4000/abstractairanica.46351

ISBN : 1961-960X

ISSN : 1961-960X

Éditeur :

CNRS (UMR 7528 Mondes iraniens et indiens), Éditions de l'IFRI

Référence électronique

Julien Cuny, « Rika Gyselen. "The Parthian Language in Early Sasanian Times » », Abstracta Iranica [En ligne], Volume 37-38-39 | 2018, document 46, mis en ligne le 30 décembre 2018, consulté le 02 octobre 2020. URL : http://journals.openedition.org/abstractairanica/46351 ; DOI : https://doi.org/ 10.4000/abstractairanica.46351

Ce document a été généré automatiquement le 2 octobre 2020.

Tous droits réservés 


\title{
Rika Gyselen. « The Parthian Language in Early Sasanian Times »
}

\author{
Julien Cuny
}

\section{RÉFÉRENCE}

Rika Gyselen. « The Parthian Language in Early Sasanian Times », Vesta Sarkhosh Curtis, Elizabeth J. Pendleton, Michael Alram, Touraj Daryaee (eds.). The Parthian and Early Sasanian Empires: Adaptation and Expansion, Proceedings of a Conference held in Vienna, 14-16 June 2012. Oxford \& Philadelphia: Oxbow Books, 2016, p. $61-68$

1 L'A. discute les seuls 5 sceaux portant une inscription en parthe mais datables selon elle de l'époque sassanide par comparaison stylistique ou iconographique (4 sceaux personnels, 1 sceau magique). Ils illustrent la survivance de l'usage de la langue parthe au début de l'époque sassanide (i.e. jusqu'au $\mathrm{IV}^{\mathrm{e}}-\mathrm{V}^{\mathrm{e}} \mathrm{s}$.), ou peut-être même d'un lien particulier (non explicité) de la langue parthe avec une iconographie ou certaines pratiques magiques. (cf. CR n 43, Rika Gyselen, « Sasanidische Siegelsteine de P. Horn et G. Steindorff revisité »).

\section{AUTEURS}

\section{JULIEN CUNY}

Conservateur au Musée du Louvre, Paris 